\title{
CELLULAR AUTOMATA AND ENERGETICS SYSTEM FORMATION
}

\author{
R. ŠIUGŽDAITE் and S. NORVAIŠAS
}

Institute of Mathematics and Informatics

Akademijos 4, 2600, Vilnius, Lithuania

E-mail: roma.siugzdaite@ven.lt, saunor@ktl.mii.lt

Received October 12, 2001; revised November 15, 2002

\begin{abstract}
Modeling complex systems requires to reduce, to organize the system complexity and to describe suitable components. Complexity of the system can then be tackled with an agentoriented approach, where local interactions lead to a global behavior. This approach helps to understand how non-deterministic behavior that is near self-organized criticality (SOC) is used to explain natural and social phenomena can emerge from local interactions between agents.

The basis of our decision to develop cellular automata (CA) as a model for energetics system formation and development in restricted region is its hypothetical dependence on and origin from the "urban slice" which is basis for "energetics slice". In the urban CA model there we introduce five types of cells representing empty area, roads, houses, water and forest. Some types of cells are introduced only for the model better correspondence to the real system and don't have essentially influence to the modeling results. We assign all cell types certain weight, which affects the probability of new "houses" cells appearance replacing "empty area" cells. Usually all cells except the empty ones have much bigger weight, therefore the dynamic of houses distribution in restricted area is organized in clusters.

A first step in model 'reliability' is an understanding how these systems behave over time. CA's are an alternative to differential equations on an attempt to model these systems. One of the most important features of CA models is its desirable capacity to capture quantitative micro-level dynamics and relate them to qualitative macro-level behavior.

Energetics system formation is dynamic process that directly depends on houses conglomerate formation, energy production and transferring prices, energy consumption factor etc. Dynamical CA model can be used to realize certain purposes of energetic policy and to make decisions about volume of production as well as prices of generation and transmission. These decisions, in one's turn, influence successive urban and energetics system dynamics. There is analyzed how various policies influence urban system development as well as its stability after the new capacity is installed and prices in generation and transmission as well as system administration are changed, etc [3]. Also there is explored how energetics system dynamics obtained with help of dynamic model corresponds with CA obtained dynamics.
\end{abstract}

Key words: Cellular automata, urban system, energetic system, self-organized criticality 


\section{CA DEFINITION}

A cellular automaton is a discrete dynamical system. Each point in a regular spatial lattice, called a cell, can have any one of a finite number of states. The states in the cells of a lattice are updated according to a local rule. That is, the state of the cell at a given time moment depends only on its own state one time step previously, and the states of its nearby neighbors at the previous time step. All cells in the lattice are updated synchronously. The state of the lattice advances in discrete time steps.

To introduce dynamic into the system, we have to add rules. The purpose of these rules is to define the state of the cell for the next time in dependence of the neighborhood cells. Different definitions of neighborhoods are possible, each one being more or less effective depending on the system you wish to model.

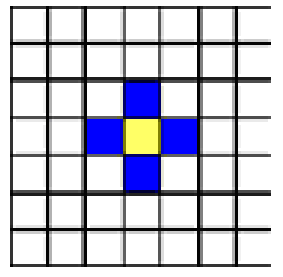

Figure 1. von Neuman Neighbourhood

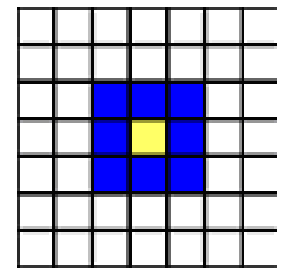

Figure 2. von Neuman Neighbourhood

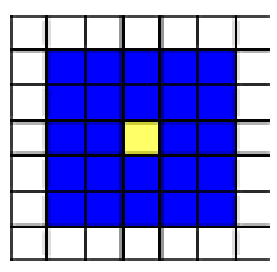

Figure 3. Moore Neighbourhood

Rules may be generalized in various ways. Each separate rule leads to patterns that differ in detail, however the examples suggest a remarkable result: all patterns appear to fall into only four qualitative classes. Wolfram characterized these basic classes of behavior into:

Class 1 - evolution tends to a homogeneous state (limiting points) in which for example all sites have value 0

Class 2 - evolution leads to a set of stable or periodic structures (limiting cycle) that are separate and simple

Class 3 - evolution leads to a chaotic pattern or 'strange attractor'

Class 4 - evolution leads to complex structures, sometimes long-lived.

The existence of only 4 classes implies universality in the behavior of CA.

The values of sites in the initial state are randomly chosen: each site taking on the value 0 or 1 with equal probability, independent of the values of other sites. Even though the initial state has no structure, evolution of the automata manifests some composition in the form of triangle 'clearings'. The spontaneous appearance of these clearings is a simple example of 'self-organization'. Both 'self-similarity' and 'self-organization' are well-characterized collective phenomena, seen often in dynamical fields. The following two properties are intimately related governing how models are studied. These models are reversibility and irreversibility.

According to L. Hurd [2], this makes CA are an ideal meeting point between 
continuous dynamics and complexity theory, since they are discretely defined but exhibit continuous dynamics.

A notable feature of CA dynamics is that all possible initial trajectories merge with time. The merging of trajectories implies that information is lost in the evolution of the cellular automaton; the evolution is irreversible. The irreversible evolution decreases the possibility of some configurations and increases those for others. The possibility of self-organization is therefore a consequence of irreversibility and the structures obtained through selforganization are determined by the characteristics of the attractors. This is an important concept in the fact that most natural systems exhibit irreversible trends in their evolution. CA models can mimic this behaviour unlike statistical mechanics, which exhibits reversible properties. While there is any evidence that the fundamental laws of physics are reversible, many systems behave irreversibly on a macroscopic scale and are appropriately described by irreversible laws. Cellular automata provide mathematical models at this macroscopic level.

\section{CA FOR URBAN SYSTEM}

Assume that energetics system development is based on the urban system dynamics. Therefore first of all we simulate with CA a real geographical situation and use it as a background for the next step - estimation for demand of new power plants. In this article we examine only the urban model.

The energetics system modelling can be divided into two major "slices": "urban" and "energetics". The urban slice describes systems behaviour as emerging from discrete entities (agents) interacting with each other. Energetics slice is concerned with describing aggregate behavior by characterizing the fundamental relationships between urban aggregations.

Our initial urban model is defined as a two-dimensional array with $L$ cells with closed boundaries. The total number of houses $N$ in the system is time dependent variable. Each cell may be occupied by one house or it may be empty. Each cell corresponds to an area segment with length $l$ and height 1. The growing of population throughout the cells is determined by a set of updating rules.

For our background model we adapt the following set of rules:

1. For all cells: if cell is empty then count sum of neighbors weights;

2. To put a new houses in lattice with certain probability according to calculated weights.

\section{MATHEMATICAL MODEL}

The finite urban domain $S$ consists of elements $s_{i j}$ of equal size. Each element except those forming the border of the domain $S$ has boundaries with 
the other eight elements. Each element $s_{i j}$ can be in one of these states:

1. empty land $-E_{i j}$;

2. river or lake $-W_{i j}$;

3. road $-R_{i j}$;

4. forest $-F_{i j}$;

5. house $-H_{i j}$;

The initial configuration of the domain $S$ changes at discrete time moments according to such a transition rule:

Element $H_{i j}$ may emerge only from the element $E_{i j}$. All the rest elements pass to themselves at discrete time moments.

Each element $s_{i j}$ has the weight $w\left(s_{i j}\right) \geq 0$, which depends on the state of the element. Since the transition rule permits the change only of element $E_{i j}$, further we shall consider the properties of these elements. The $k$-vicinity of element $E_{i j}$ in the land state is formed of all the elements distant from the $E_{i j}$ no more than by $k$ elements. E.g., 1 - vicinity consists of 9 adjacent elements (including the element $E_{i j}$ itself), etc.

The total amount of elements constituting the $k$ - vicinity

$$
w^{k}\left(E_{i j}\right)=\sum_{\substack{i-k \leq l \leq i+k \\ j-k \leq m \leq j+k}} w\left(s_{l m}\right) .
$$

It should be noted that the larger the $k$ - weight $w\left(E_{i j}\right)$ of the element, the greater the probability for the land element $E_{i j}$ to pass into the state $H_{i j}$.

\section{ALGORITHM}

The states to all the elements of the domain $S$ are attributed so that the domain corresponds to some real or fictitious urban situation. The initial situation will change at discrete time moments. We choose the environment $k>0$. The $k$ - weight $w^{k}\left(E_{i j}\right)$ is computed to each land element $E_{i j}$. Since the weights of elements making up the $k$ - environment in this model do not depend on the distance to $E_{i j}$, too large an environment equalize the weights of elements $E_{i j}$. Therefore, in fact $k$ is not to be too large. The sum of $k$ - weights of all elements $E_{i j}$ of the region $S$ is $E_{i j}$, and the $k$ - weight of element $E_{i j}$ is a part $\frac{w^{k}\left(E_{i j}\right)}{w^{k}(S)}$ of the total sum. The interval of length $w^{k}(S)$ is consecutively filled by partial intervals of length $w^{k}\left(E_{i j}\right)$. In this interval a uniformly distributed random variable is generated. A random value indicated the interval, to the element of which the transition rule is applied: the state $E_{i j}$ is changed into the state $H_{i j}$. After this phase stage, the weights of the remaining elements $E_{i j}$ (there are less of them by a unit) are recomputed and a random variable generated again. 


\section{SIMULATION RESULTS}

Using this model there were done calculations that allow us to calibrate weights value looking for the best fit to real system. It was chosen initial urban pattern (Fig. 4). We have got settlement centralization with parameters values: $w^{1}(E)=0, w^{1}(H)=999$ (Fig.5), but it isn't specific feature to real urban systems. Another test was done with $w^{1}(E)=10, w^{1}(H)=50$ (Fig.6) and we received homogeneous urban dynamics that doesn't look realistic too. The best-fit parameters to real system were $w^{1}(E)=3, w^{1}(H)=800$ (Fig.7). Within the given values we have different size of clusters. To put all calculations results into logarithmic scale we will see the law approximate to $\log$ - $\log$ distribution.

It will be observed initial situation doesn't have essential influence to conglomerates with the same weights distribution. We can follow that from Fig. 8 and diagram of clusters distribution. That means that only proportion of two quantities $-E$ and $H-$ is dominant in urban system formation.

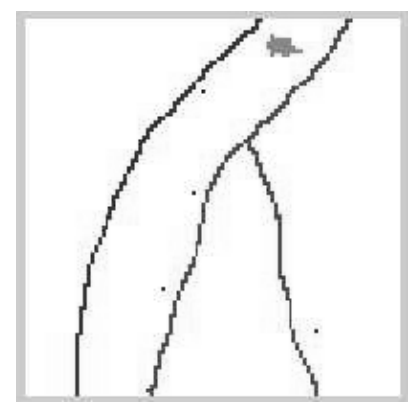

Figure 4. Initial urban landscape.

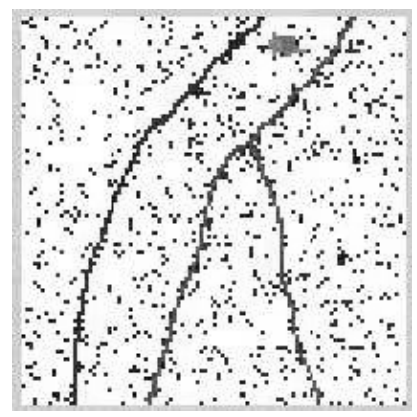

Figure 6. Urban homogeneity $\left(w^{1}(E)=50, w^{1}(H)=50\right)$

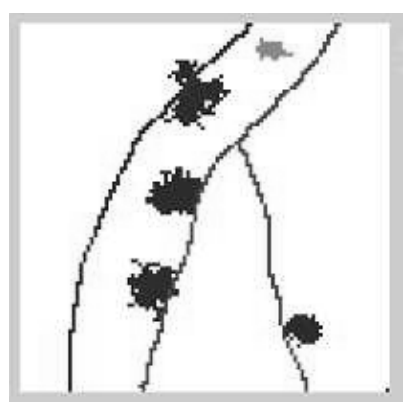

Figure 5. Urban superconcentration

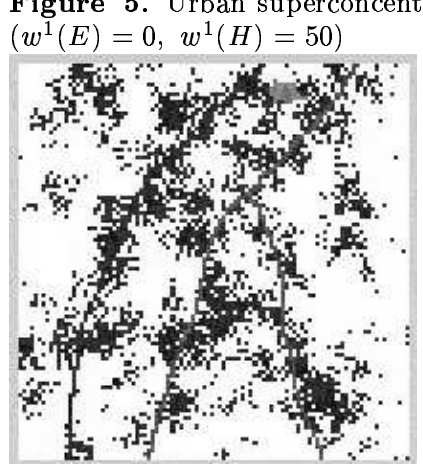

Figure 7. Urban situation close to real distribution $\left(w^{1}(E)=3, w^{1}(H)=800\right)$ 


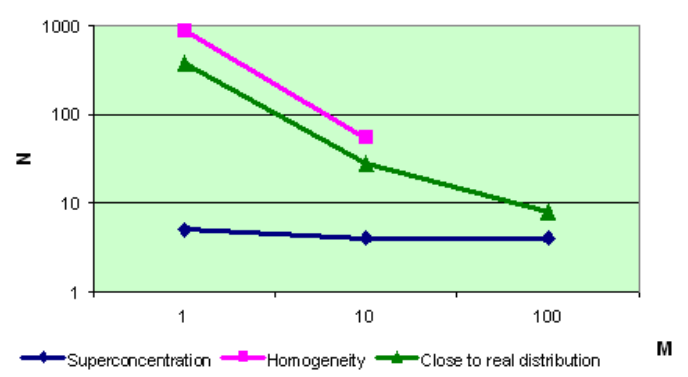

Figure 8. Diagram of clusters log-log distribution

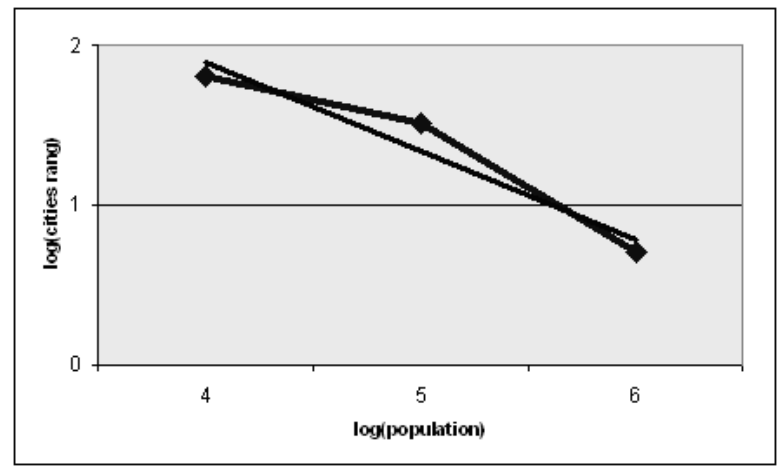

Figure 9. Diagram of cities according to population in Lithuania.

In Fig.7 after 4000 time steps we can see simulated situation where the biggest concentration of houses appear near roads, water and forest. Distribution of simulated conglometares in Fig. 5,6,7 is shown in Fig.8. Modeling shows that conglomerate log-log distribution according to doesn't depend on initial pattern, only on weights of houses $H_{i j}$ and empty place $E_{i j}$. On Fig.10 there are simulation results, when initian pattern contains only empty place cells. Figures 4, 5, 6, 7 shows the application of these updating rules to an example system with $100 \times 100$ cells.

\section{CONCLUSION}

Model analysis and simulation results enable us to conclude about its adequacy to real urban system. Urban dynamics mainly depends on two parameters (cell weights): empty places and houses. Changing proportion of these weights we can calibrate them and get the most suitable to real system dynamical behavior. Multiple simulations demonstrate that marginal length $L$ 

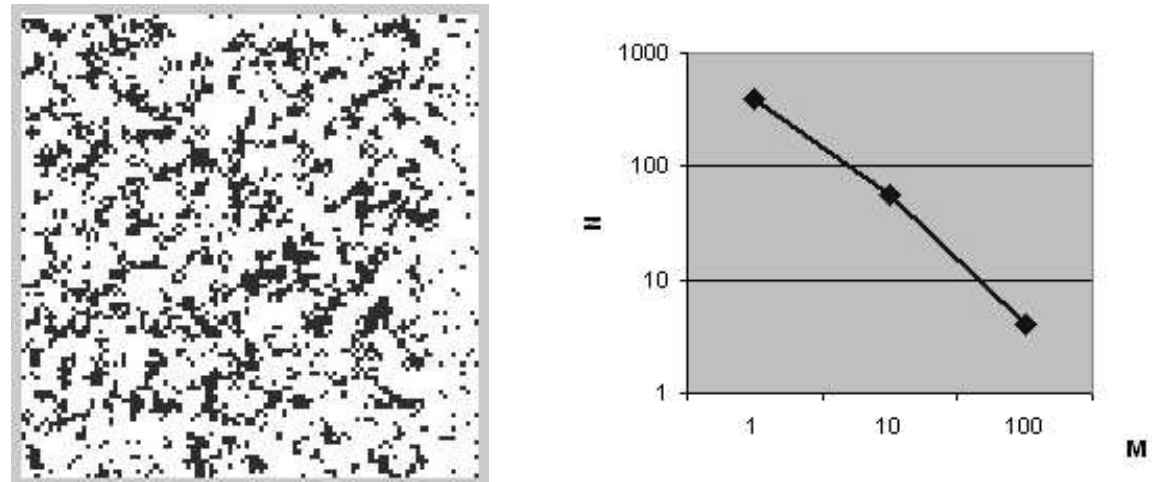

Figure 10. Situation simulated on Figure 11. Power law of situation in empty pattern $\left(w^{1}(E)=30, w^{1}(H)=\right.$ Fig. 6 1200)

of the modeling area should be between 100 and 1000 cells. If there are less of them we don't get conglomerates bigger that $10^{2}$, so we can't do calibration of the parameters. On another hand, if $L$ is larger $10^{3}$ we don't receive any new information about parameters.

In this paper we choose to demonstrate how could be used CA in urban system modeling. Further on the background of this model we'll compose dynamical model of energetics system. We must see that SOC is subsistent to urban system.

Finding this fact allow us to use obtained statistical information about energetics system (capacity of generators, their distribution) in making decisions about system development and analyzing influence of various solutions to system dynamics, energy demand, generation costs and etc.

\section{REFERENCES}

[1] P. Bak. How Nature Works: The Science of Self-Organised Criticality. New York, 1996.

[2] M. Barnsley and L. Hurd. Fractal Image Compression. AK Peters, Wellesley, 1993.

[3] Benjaafar and Saifallah et al. Cellular Automata for Traffic Flow Modeling. Univ. of Minnesota, Minneapolis, 1997.

[4] Richard Cochinos. Introduction to the Theory of Cellular Automata and OneDimensional Traffic Simulation.

[5] I. Dyner and Ra Smith. Pena Ge System Dynamics Modelling for Residential Energy Efficiency Analysis and management. Journal of The Operational Research Society, 46(10), 1163 - 1173, 1995.

[6] A. Ford. System Dynamics and the Electric Power Industry. System Dynamics Review, $\mathbf{1 3}(1), 57-85,1997$. 
[7] Howard Howard Gutowitz. Alife Online. CA FAQ, Santa Fe Institute, 1999. http://alife.santafe.edu/alife/topics/cas/ca-faq/ca-faq.html

[8] S. Norvaisas. Modelling of Urban processes by Cellular Automata. 1995.

[9] Alexander Schatten. Cellular Automata Digital Worlds. http://qspr03.tuwien.ac.at/ aschatt/info/ca/ca.html.

[10] M. Schroeder. Fractals, Chaosi, Power Laws. New York, 1991.

[11] Moshe Sipper. A brief introduction to Cellular Automata. http://lslwww.epfl.ch/moshes/ca.html.

[12] Stephan Wolfram. Cellular Automata and Complexity. Addison-Wesley, Menlo Park, 1994.

\section{Ląstelių automatai ir energetinès sistemos susidarymas}

S. Norvaišas, R. Šiugždaitè

Pasiūlytas efektyvus ląstelių automatų (LA) modelis, aprašantis sudètingą urbanistinę sistemą (namų konglomeratų) krizinès savirangos aspektu. Krizinès savirangos būsena (KSB) yra būdinga daugeliui sudètingu dinaminiu sistemų, tame tarpe ir urbanistinei bei energetinei sistemai. Šiame straipsnyje nagrinejamas urbanistiniu klasteriu formavimasis ir parametrų, kurie labiausiai atitinka KSB, nustatymas. Pažymima, kad energetinė sistema, kuri yra apibūdinama generatorių kiekio pagal galingumą pasiskirstymu, yra išvestinè iš urbanistinès sistemos, todèl jai tinka urbanistinès sistemos LA modelis. 